Article

\title{
Physical Stress Induced Reduction of Proliferating Cells and Differentiated Neuroblasts Is Ameliorated by Fermented Laminaria japonica Extract Treatment
}

\author{
Hyo Young Jung ${ }^{1} \oplus$, Woosuk Kim ${ }^{1,2}$, Hyun Jung Kwon ${ }^{3}$, Dae Young Yoo ${ }^{4} \oplus$, Sung Min Nam ${ }^{5}$, \\ Kyu Ri Hahn ${ }^{1}$, Sun Shin Yi ${ }^{6}$, Jung Hoon Choi ${ }^{7}$, Dae Won Kim ${ }^{3}{ }^{\circledR}$, Yeo Sung Yoon ${ }^{1}$ and \\ In Koo Hwang 1,*(D) \\ 1 Department of Anatomy and Cell Biology, College of Veterinary Medicine, and Research Institute for \\ Veterinary Science, Seoul National University, Seoul 08826, Korea; hyoyoung@snu.ac.kr (H.Y.J.); \\ tank3430@hallym.ac.kr (W.K.); hkinging@snu.ac.kr (K.R.H.); ysyoon@snu.ac.kr (Y.S.Y.) \\ 2 Department of Biomedical Sciences, and Research Institute for Bioscience and Biotechnology, \\ Hallym University, Chuncheon 24252, Korea \\ 3 Department of Biochemistry and Molecular Biology, Research Institute of Oral Sciences, College of Dentistry, \\ Gangneung-Wonju National University, Gangneung 25457, Korea; donuts25@gwnu.ac.kr (H.J.K.); \\ kimdw@gwnu.ac.kr (D.W.K.) \\ 4 Department of Anatomy, College of Medicine, Soonchunhyang University, Cheonan 31151, Korea; \\ dyyoo@sch.ac.kr \\ 5 Department of Anatomy, School of Medicine and Institute for Environmental Science, Wonkwang University, \\ Iksan 54538, Korea; namvet1@wku.ac.kr \\ 6 Department of Biomedical Laboratory Science, College of Medical Sciences, Soonchunhyang University, \\ Asan 31538, Korea; admiral96@sch.ac.kr \\ 7 Department of Anatomy, College of Veterinary Medicine and Institute of Veterinary Science, \\ Kangwon National University, Chuncheon 24341, Korea; jhchoi@kangwon.ac.kr \\ * Correspondence: vetmed2@snu.ac.kr
}

Received: 21 October 2020; Accepted: 18 November 2020; Published: 24 November 2020

\begin{abstract}
Laminaria japonica is widely cultivated in East Asia, including South Korea. Fucoidan, a main component of $L$. japonica, protects neurons from neurological disorders such as ischemia and traumatic brain injury. In the present study, we examined the effects of extract from fermented L. japonica on the reduction of proliferating cells and neuroblasts in mice that were physically (with electric food shock) or psychologically (with visual, auditory and olfactory sensation) stressed with the help of a communication box. Vehicle (distilled water) or fermented L. japonica extract $(50 \mathrm{mg} / \mathrm{kg}$ ) were orally administered to the mice once a day for 21 days. On the 19th day of the treatment, physical and psychological stress was induced by foot shock using a communication box and thereafter for three days. Plasma corticosterone levels were significantly increased after exposure to physical stress and decreased Ki67 positive proliferating cells and doublecortin immunoreactive neuroblasts. In addition, western blot analysis demonstrated that physical stress as well as psychological stress decreased the expression levels of brain-derived neurotrophic factor (BDNF) and the number of phosphorylated cAMP response element binding protein (pCREB) positive nuclei in the dentate gyrus. Fermentation of $L$. japonica extract significantly increased the contents of reduced sugar and phenolic compounds. Supplementation with fermented L. japonica extract significantly ameliorated the increases of plasma corticosterone revels and decline in the proliferating cells, neuroblasts, and expression of BDNF and pCREB in the physically stressed mice. These results indicate that fermented L. japonica extract has positive effects in ameliorating the physical stress induced reduction in neurogenesis by modulating BDNF and pCREB expression in the dentate gyrus.
\end{abstract}


Keywords: stress; corticosterone; fermented Laminaria japonica extract; dentate gyrus; neurogenesis

\section{Introduction}

The hippocampus in brain is related to limbic system and is closely related to learning and memory formation as well as emotions [1]. It is the most vulnerable region of the brain to ischemic damage and amyloid- $\beta$ deposition [2,3]. In addition, the hippocampus is one of the most active regions in terms of the generation of new neurons throughout a person's lifetime [4]. Stem cells in adult brain are located in the unique brain region such as subgranular zone of the dentate gyrus and are able to proliferate and differentiate into neuroblasts [4]. Newly generated mature neurons in granule cell layer contribute to hippocampus-dependent learning and memory processes [5-8]. Several lines of evidence have demonstrated that promotion of neurogenesis improves memory performance [9], while memory impairments are caused by impairments of hippocampal neurogenesis $[10,11]$.

Stress reduces hippocampal neurogenesis in adult brains of mice and rats [12]. The cognitive performance was closely related to circulating glucocorticoid concentration in blood [13,14]. In non-human primates, stress induced by social isolation increases plasma cortisol levels and decreased cell proliferation and neuroblasts in the hippocampus [15]. In human brain, the functional connectivity is enhanced in the parahippocampal cortex with middle temporal gyrus after stress, indicating the stress affects the hippocampal memory formation in human [16]. Previously, our colleagues demonstrated that adrenalectomy significantly decreases plasma corticosterone levels, while removal of adrenal gland increases proliferating cells and neuroblasts in the dentate gyrus 5 days after surgery [17]. Increases in glucocorticoid concentration due to chronic stress exacerbates the degeneration of neurons induced by acute alcohol binging [18], the onset and progression of Alzheimer's disease [19], and Parkinson's disease [20]. Psychological stress does not reduce the number of neuroblasts/immature neurons in the hippocampus of ICR mice although high fat diet-fed mice presented significantly decreased neuroblasts [21]. In contrast, prenatal exposure to psychological stress significantly decreases the proliferating cells in the dorsal hippocampus [22].

Laminaria japonica Aresch., a brown alga, is cultivated in East Asia, including South Korea, Japan, and China. It has been consumed as a marine vegetable and has various pharmacological effects especially pertaining to neurological disorders [23-25] and metabolic diseases [26]. L. japonica contains lipophilic components such as fucoxanthin and fucosterol as well as hydrophilic fibers including alginate and fucoidan. Fucoidan, a functional component of $L$. japonica, has neuroprotective effects against ischemia, traumatic brain injury, and Parkinson's disease [27-30]. Recently, marine seaweeds have been indicated as a new generation source for natural medicines for the treatment of neurological disorders [31-34]. Fermentation tools has great attention to enhance biological functions and to increase the yield the specific substances because fermentation with microorganism splits the complex compounds into simple ones [35,36]. Fermented L. japonica extract (fLJE) shows more potent antioxidant and anti-inflammatory activities compared to that in the general LJE [37,38]. Recent studies demonstrated that fermented L. japonica showed neuroprotective effects against scopolamine- and ethanol-induced amnesia in mice [39] as well as trimethyltin-induced memory deficits in rats [40]. However, there are currently no studies that detail the effects of fermented L. japonica on proliferating cells and neuroblasts in physically or psychologically stressed mice.

Therefore, in the present study, we investigated the effects of fLJE on Ki67-positive proliferating cells and doublecortin (DCX)-immunoreactive neuroblasts in the dentate gyri of mice exposed to physical or psychological stress. 


\section{Results}

\subsection{Changes of Sugar and Total Phenolic Compound Contents}

Total and reducing sugar contents were significantly increased after fermentation. Especially reducing sugar contents were dramatically increased by 43.2 -folds after fermentation. In addition, total phenolic compounds were significantly increased by 1.66-folds after fermentation although the statistical significance was not detected between groups (Table 1).

Table 1. Contents of total and reducing sugars as well as total phenolic compounds are analyzed by spectrophotometric methods before and after fermentation of LJE.

\begin{tabular}{cccc}
\hline Sample & $\begin{array}{c}\text { Total Sugars } \\
(\mathbf{m g} / \mathbf{m L})\end{array}$ & $\begin{array}{c}\text { Reducing Sugars } \\
\mathbf{( m g / m L )}\end{array}$ & $\begin{array}{c}\text { Total Phenolic Compounds } \\
\mathbf{( M g} / \mathbf{m L})\end{array}$ \\
\hline Before (LJE) & $3.51 \pm 0.29$ & $4.85 \pm 2.69$ & $2.48 \pm 0.32$ \\
After (fLJE) & $6.02 \pm 0.69^{\mathrm{a}}$ & $209.51 \pm 16.52^{\mathrm{a}}$ & $4.11 \pm 0.25^{\mathrm{a}}$ \\
\hline
\end{tabular}

Values are mean \pm standard deviation $\left(n=5\right.$; ${ }^{\text {a }}<0.05$, significantly different from the LJE group).

\subsection{Effect of fLJE on Plasma Corticosterone Levels in Physically and Psychologically Stressed Mice}

Plasma corticosterone level was $127.02 \mathrm{ng} / \mathrm{mL}$ in the control group. In the physically stressed group induced by foot-shock stress (FS group), plasma corticosterone levels dramatically increased by 3.31-fold compared to the control group, while in the psychologically stressed group induced by in non-food-shock stress (NFS group), plasma corticosterone levels did not show any significant changes compared to the control group. Statistical significance was observed only between the control and FS groups. In the fLJE-treated FS group (fLJE + FS group), plasma corticosterone levels decreased significantly down to $69.81 \%$ of the FS group. In the fLJE-treated NFS group (fLJE + NFS group), plasma corticosterone levels did not show any significant changes compared to those of the NFS group (Figure 1).
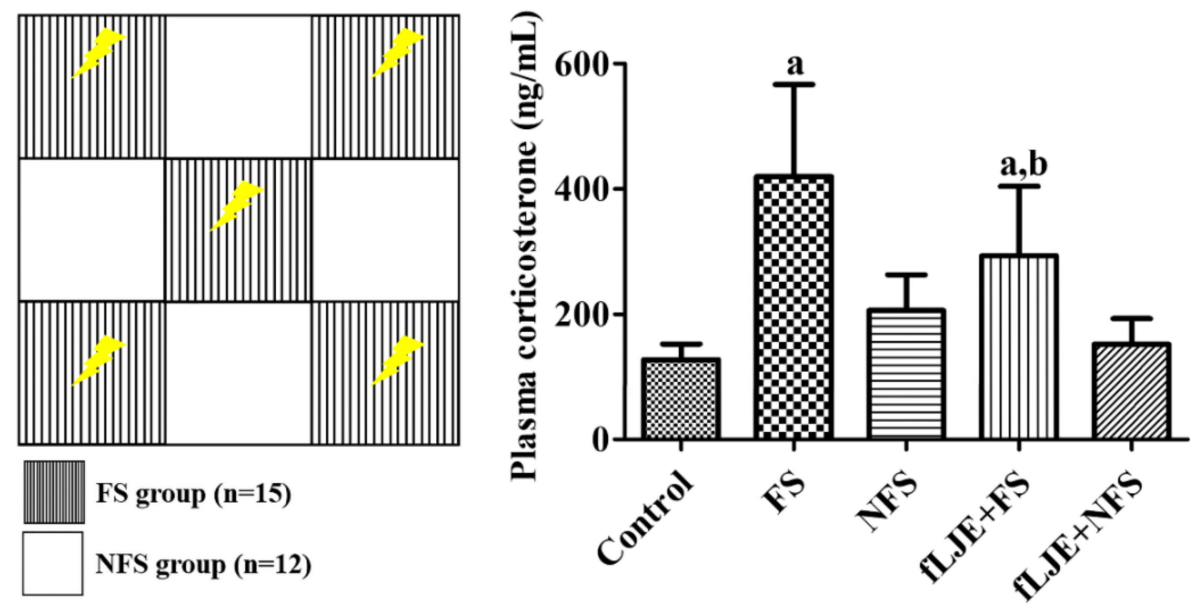

Figure 1. Depicted drawing of the communication box used in the present study. The electric shock is induced in FS group compartment, while in NFS group compartment there are no electric shock. However, animals feel visual, auditory and olfactory sensation from FS group. Plasma corticosterone levels in the control, foot-shock stress (FS) group, non-foot-shock stress (NFS) group, FS with fermented Laminaria japonica (fLJE) treatment (fLJE + FS) group, and NFS group with fLJE treatment (fLJE + NFS) ( $n=12$ or 15 per group; ${ }^{\mathrm{a}} p<0.05$, significantly different from the control group; ${ }^{\mathrm{b}} p<0.05$, significantly different between the FS and fLJE + FS groups). Bars indicate the standard deviation. 


\subsection{Effect of fLJE on Cell Proliferation in Physically and Psychologically Stressed Mice}

In the control group, proliferating cells expressing Ki67 were detected mainly in the subgranular zone of the dentate gyrus (Figure 2A). In this group, the mean number of Ki67-positive nuclei in the dentate gyrus was 10.24 per section (Figure 2F). In the FS and NFS groups, significantly fewer Ki67-positive nuclei were found in the subgranular zone of the dentate gyrus compared to the control group and the mean number of Ki67-positive nuclei was 4.85 and 6.15 per section, respectively (Figure 2B,C,F). In the fLJE-FS and fLJE-NFS groups, Ki67-positive nuclei were abundantly observed in the subgranular zone of the dentate gyrus and the number was significantly higher $(332.73 \%$ and $172.63 \%$, respectively) in these groups than in the FS and NFS groups (Figure 2D-F).

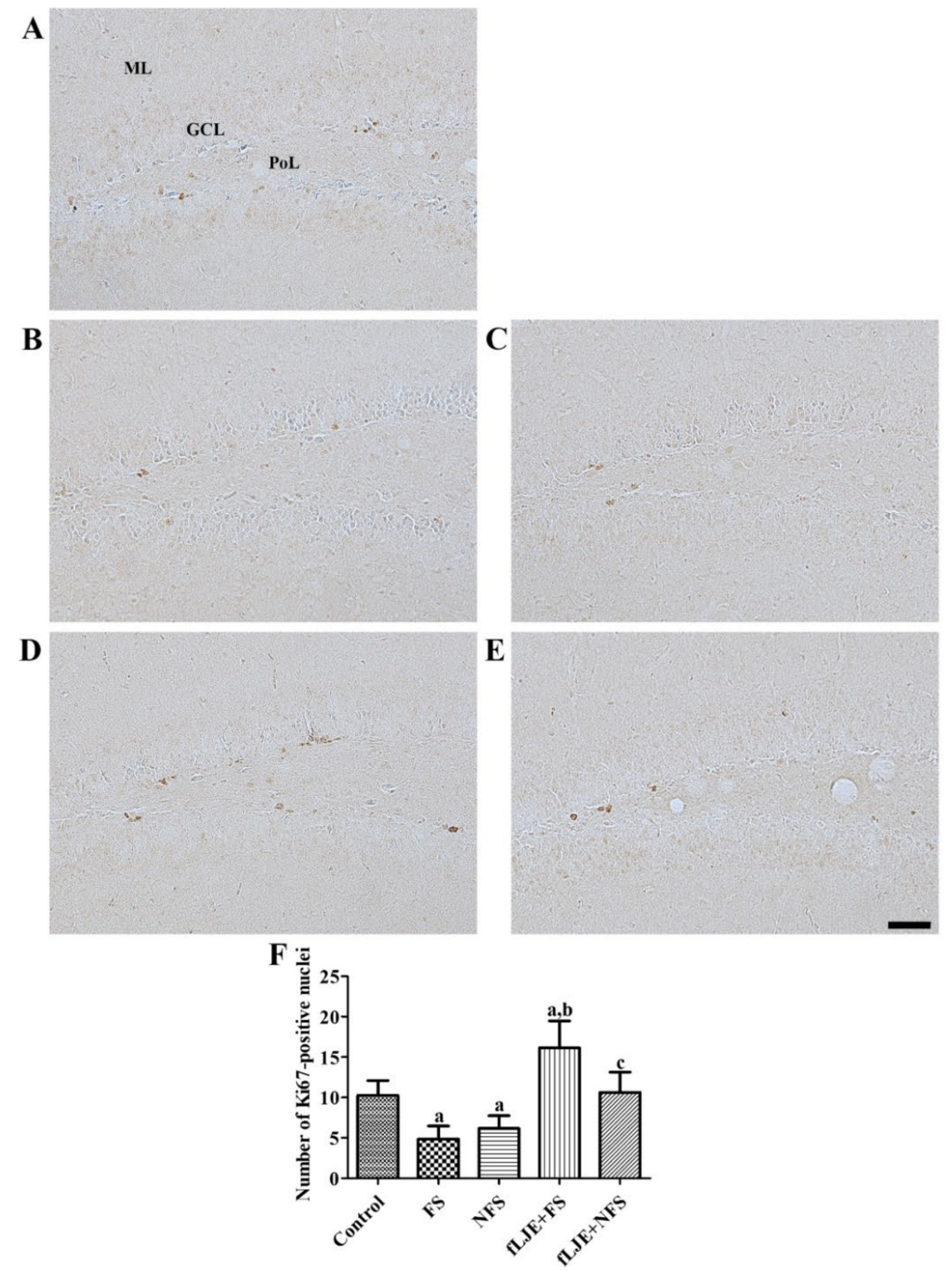

Figure 2. Immunohistochemistry for Ki67 in the dentate gyrus of the control (A), foot-shock stress (FS) group (B), non-food-shock stress (NFS) group (C), FS with fermented Laminaria japonica (fLJE) treatment (fLJE + FS) group (D), and NFS group with fLJE treatment (fLJE + NFS) (E), GCL, granule cell layer; ML, molecular layer; PoL, polymorphic layer. Scale bar $=50 \mu \mathrm{m}$. (F) The mean number of Ki67-positive cells per section in all the groups ( $n=6$ or 8 per group; ${ }^{\mathrm{a}} p<0.05$, significantly different from the control group; ${ }^{\mathrm{b}} p<0.05$, significantly different between the FS and fLJE + FS groups; ${ }^{\mathrm{c}} p<0.05$, significantly different between the NFS and fLJE + NFS groups). Bars indicate the standard deviation. 


\subsection{Effect of fLJE on Neuroblast Differentiation in Physically and Psychologically Stressed Mice}

In the control group, differentiated neuroblasts expressing DCX were observed in the dentate gyrus. Their cytoplasm was located in the subgranular zone of the dentate gyrus and their dendrites extended into the molecular layer of the dentate gyrus (Figure 3A,B). In the FS and NFS groups, DCX-immunoreactive neuroblasts were less abundantly detected in the dentate gyrus compared to the control group (Figure 3C-F). DCX immunoreactivity in these groups was significantly decreased by $53.35 \%$ and $56.57 \%$ of the control group, respectively (Figure 3K). In the fLJE + FS group, DCX-immunoreactive neuroblasts were abundantly detected in the dentate gyrus (Figure 3G,H). DCX immunoreactivity in this group was significantly increased compared to the FS group and was similar to that of the control group (Figure 3K). In the fLJE + NFS group, DCX immunoreactivity was similar to that in the NFS group (Figure 3I-K).
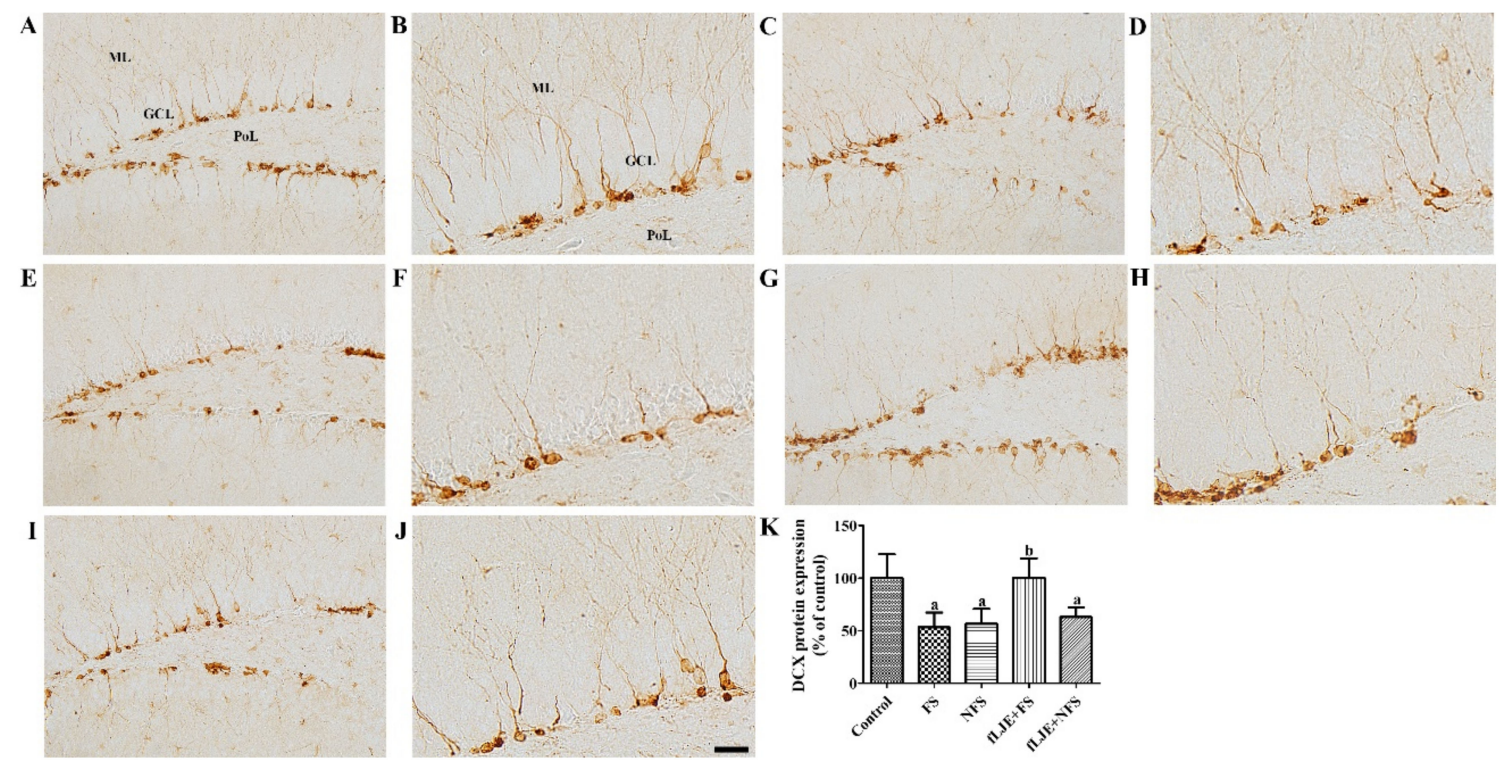

Figure 3. Immunohistochemistry for doublecortin (DCX) in the dentate gyrus of the control (A) and (B), foot-shock stress (FS) group (C) and (D), non-food-shock stress (NFS) group (E and F), FS with fermented Laminaria japonica (fLJE) treatment (fLJE + FS) group (G) and (H), and NFS group with fLJE treatment (fLJE + NFS, I and J). GCL, granule cell layer; ML, molecular layer; PoL, polymorphic layer. Scale bar $=50 \mu \mathrm{m}(\mathbf{A}, \mathbf{C}, \mathbf{E}, \mathbf{G}, \mathbf{I})$ or $25 \mu \mathrm{m}(\mathbf{B}, \mathbf{D}, \mathbf{F}, \mathbf{H}, \mathbf{J})$. (K): The relative optical densities (RODs) expressed as a percentage of the value representing the DCX immunoreactivity in the dentate gyrus of the control group are shown ( $n=6$ or 8 per group; ${ }^{a} p<0.05$, significantly different from the control group; ${ }^{\mathrm{b}} p<0.05$, significantly different between FS and FS-fLJE groups). Bars indicate the standard deviation.

\subsection{Effect of fLJE on Phosphorylated Camp Response Element Binding Protein (Pcreb) Expression in Physically and Psychologically Stressed Mice}

In the control group, pCREB immunoreactivity was observed in the dentate gyrus, and was especially abundant in the subgranular zone of the dentate gyrus (Figure $4 \mathrm{~A}$ ). In this group, the mean number of pCREB-positive nuclei was 137.74 in the subgranular zone of the dentate gyrus per section (Figure 4F). In the FS and NFS groups, pCREB-positive nuclei were less abundant in the dentate gyrus compared to the control group (Figure 4B,C). In these groups, the number of pCREB-positive nuclei in the subgranular zone of the dentate gyrus was $60.31 \%$ and $51.44 \%$ of the control group, respectively (Figure 4F). In the fLJE + FS group, pCREB-positive nuclei were abundant in the subgranular zone of the dentate gyrus and the number was significantly increased compared to the FS group (Figure $4 D, F$ ). In the fLJE + NFS group, more pCREB-positive nuclei were found in the subgranular zone of the dentate gyrus compared to the NFS group although statistically significant difference were not detected (Figure 4E,F). Western blot analysis showed similar levels of CREB protein in all groups, while pCREB/CREB protein 
levels in the FS and NFS groups were significantly decreased down to $57.4 \%$ and $41.6 \%$ of control group, respectively. However, $\mathrm{pCREB} / \mathrm{CREB}$ protein levels were significantly increased in the fLJE + FS group by 1.97 -fold of FS group and similar level to control group. In the fLJE + NFS group, pCREB/CREB protein levels were also significantly increased by 1.94-fold of NFS group (Figure 4G).

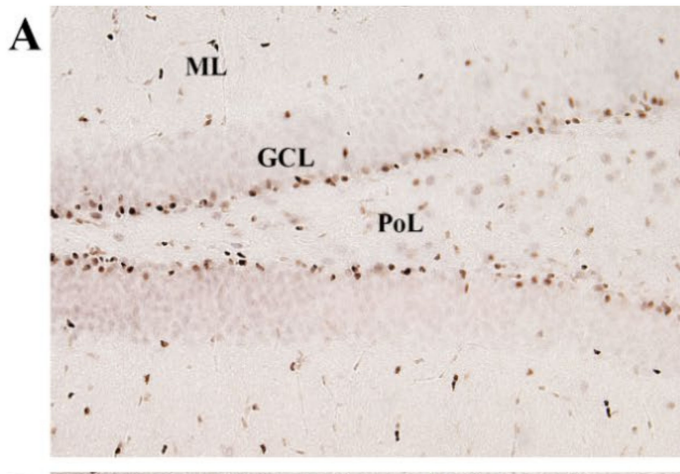

B

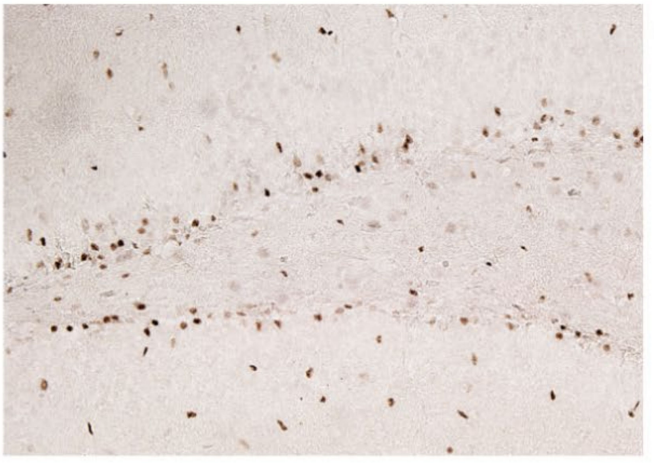

D

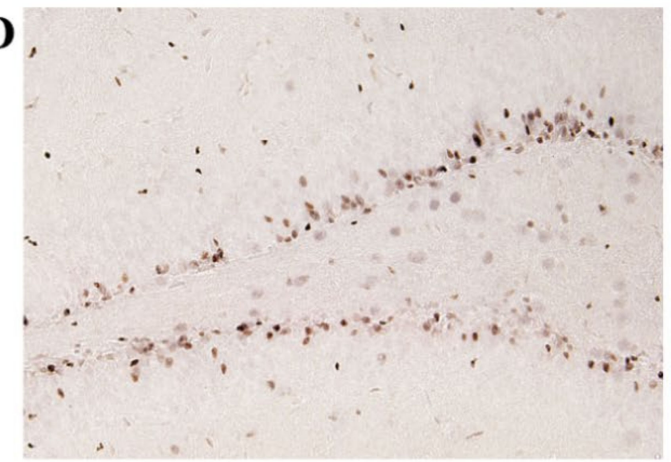

$\mathbf{F}$

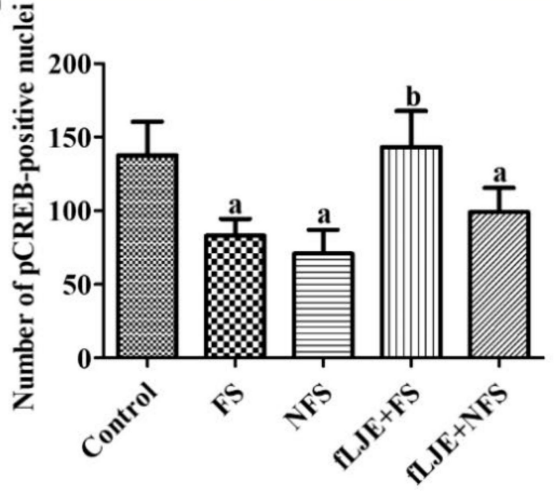

C

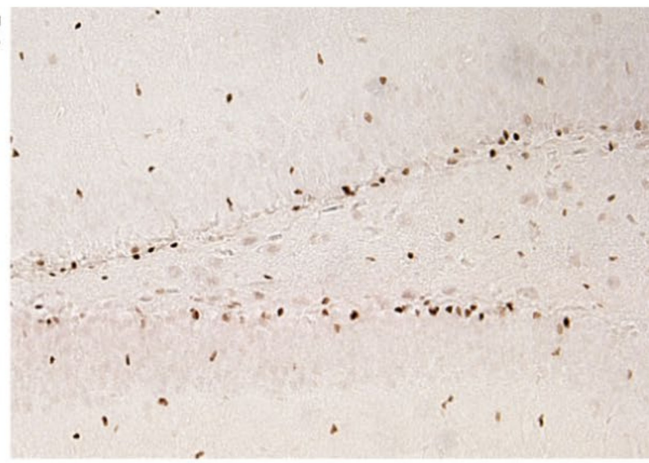

$\mathbf{E}$

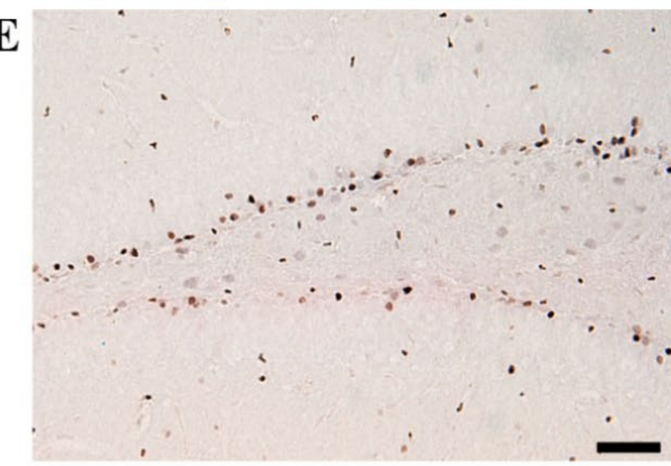

G

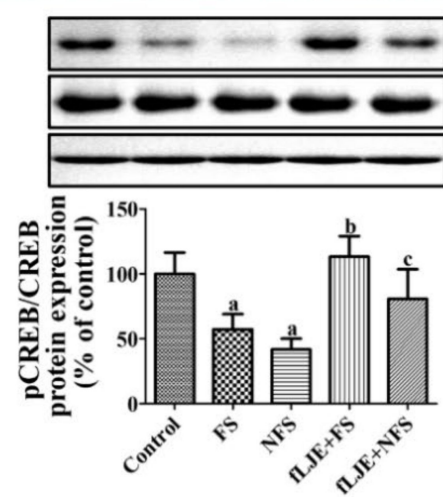

Figure 4. Immunohistochemistry for phosphorylated cAMP response element binding protein (pCREB) in the dentate gyrus of the control (A), foot-shock stress (FS) group (B), non-food-shock stress (NFS) group (C), FS with fermented Laminaria japonica (fLJE) treatment (fLJE + FS) group (D), and NFS group with fLJE treatment (fLJE + NFS, (E). GCL, granule cell layer; ML, molecular layer; PoL, polymorphic 
layer. Scale bar $=50 \mu \mathrm{m}$. $(\mathbf{F})$ : The mean number of pCREB-positive cells per section in all groups is shown. (G): Western blot analysis, expressed as a percentage of the value of the phosphorylated cAMP response element binding protein (pCREB) and CREB immunoblot bands of the control group, respectively. Data were represented to the percentage of PCREB/CREB ratio in each lane $(n=5$ or 7 per group; ${ }^{a} p<0.05$, significantly different from the control group; ${ }^{b} p<0.05$, significantly different between FS and FS-fLJE groups; ${ }^{c} p<0.05$, significantly different between the NFS and fLJE + NFS groups). Bars indicate the standard deviation.

\subsection{Effect of fLJE on BDNF Expression in Physically and Psychologically Stressed Mice}

In the FS group, BDNF mRNA and protein levels in the hippocampal dentate gyrus were significantly decreased down to $46.3 \%$ and $68.93 \%$ compared to the control group, respectively. In the NFS group, BDNF mRNA and protein levels showed similar reduction (down to 54.1\% and 74.05\% of control group) compared to the control group, respectively. In the fLJE + FS group, BDNF mRNA and protein levels were increased by 3.09 and 1.57-folds of FS group, respectively, and were slightly higher than in the control group. In the fLJE + NFS group, BDNF mRNA level was significantly increased compared to the NFS group, but no changes of BDNF levels were detected in the hippocampal homogenates between NFS and fLJE + NFS group (Figure 5).
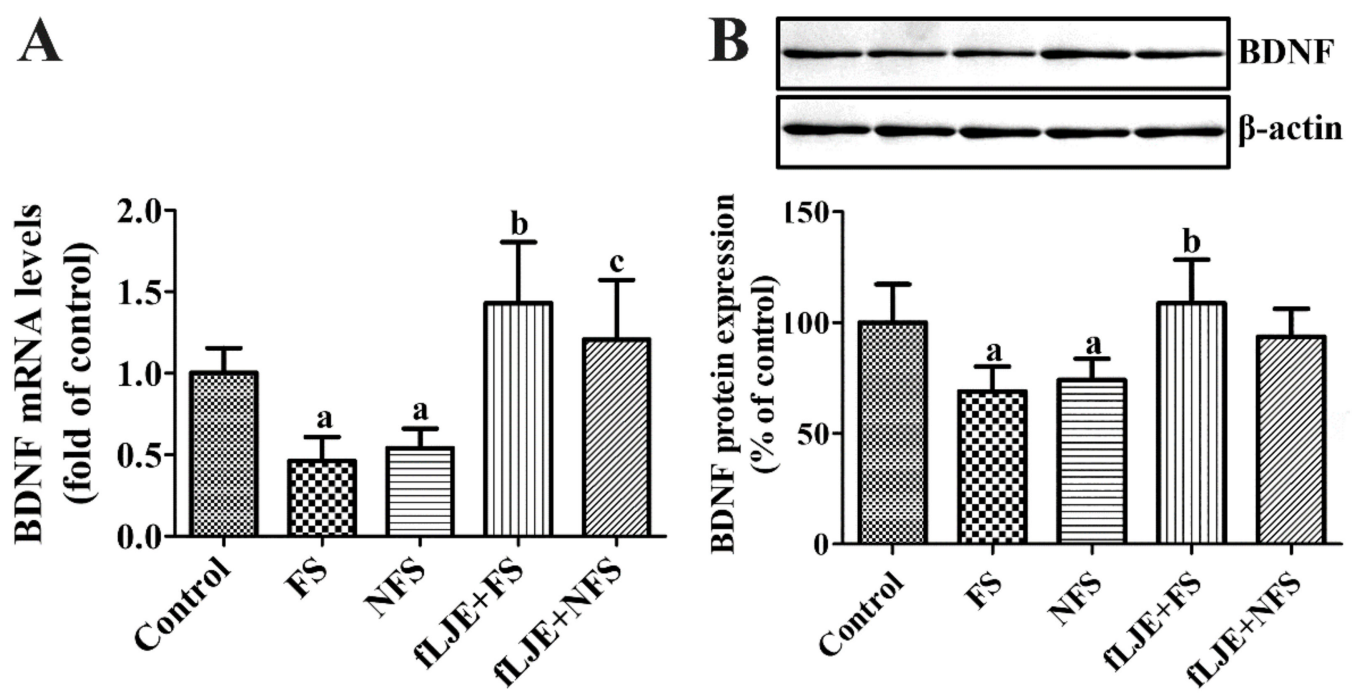

Figure 5. Quantitative real-time polymerase chain reaction (A) and western blot analysis (B) in the control, foot-shock stress (FS) group, non-food-shock stress (NFS) group, FS with fermented Laminaria japonica (fLJE) treatment (fLJE + FS) group, and NFS group with fLJE treatment (fLJE + NFS), expressed as a relative amount of brain-derived neurotrophic factor (BDNF) mRNA and percentage of the value of the BDNF immunoblot band of the control group. Data from quantitative real-time polymerase chain reaction were analyzed using the method of $2^{-\Delta \Delta} \mathrm{Ct}$ and presented relative to the control group and western blot data were normalized to $\beta$-actin levels in each lane $\left(n=5\right.$ or 7 per group; ${ }^{a} p<0.05$, significantly different from the control group; ${ }^{\mathrm{b}} p<0.05$, significantly different between FS and fLJE + FS groups; ${ }^{c} p<0.05$, significantly different between the NFS and fLJE + NFS groups). Bars indicate the standard deviation.

\section{Discussion}

Transient mild to moderate stress enhances the compensatory adaptive ability to overcome stressful events, while long-lasting stress causes various problems including mental disorders [41-43]. In the present study, we used a communication box to induce physical and psychological stress in mice and examined the effects of fLJE on plasma corticosterone levels in these mice. Physical 
stress elevated plasma corticosterone levels by 3.31-fold compared to those in the control group, while plasma corticosterone levels did not show significant changes in psychologically stressed mice. This result is partially consistent with previous studies indicating that serum corticosterone levels are significantly increased in both physically and psychologically stressed groups compared to their control groups $[44,45]$. This discrepancy may be associated with the susceptibility of males and females to chronic stress because neurochemical profiling shows that females are more vulnerable to stress than males [46-49]. Other groups demonstrated that psychological stress using a communication box increased acutely blood corticosterone levels but did not change after 15 or 30 days-stress exposure $[45,50]$. Repeated injection stress for 6 weeks increased corticosterone reactivity, while the social isolation decreased the corticosterone reactivity [51]. We assumed that corticosterone is more reactive to physical stress than psychological stress and we observed the significant reduction of corticosterone levels in physical, not psychological stress.

Enhancement of hippocampal neurogenesis decreases corticosterone-induced anxiety and depression-related behaviors in mice [52]. In contrast, ablation of hippocampal neurogenesis in mice shows reduced anxiety-like behavior during the dark cycle and exacerbates the decreases in corticosterone levels after restraint stress [53]. In the present study, we observed the effects of fLJE on cell proliferation and neuroblast differentiation in physically and psychologically stressed mice. Physical and psychological stress significantly decreased the number of proliferating cells and neuroblasts in the dentate gyrus compared to the control group. Predator stress significantly reduced the number of bromodeoxyuridine and DCX double positive cells in the dentate gyrus compared to the control group [54]. In addition, early life stress significantly decreased the number of proliferating cells and neuroblasts in the dentate gyrus [55]. There is a contradictory report indicating that DCX-immunoreactive neuroblasts are similarly observed in control and psychologically stressed mice 7 days after the last stress session while high fat diet-fed ICR mice showed significant decreases in DCX-immunoreactive neuroblasts 7 days after the last stress session compared to high diet-fed control mice [21]. This discrepancy may be associated with the duration and intensity of the electric shocks, and the euthanization time after the last stress session. In the present study, the administration of fLJE significantly increased the number of proliferating cells and neuroblasts in physically stressed mice, but not in the psychologically stressed mice. Several studies have demonstrated that red, green, and brown algae enhance neurogenesis [56-58]. In addition, fucoidan derived from Fucus vesiculosus and Undaria pinnatifida promoted neurite outgrowth in PC12 cells [59].

In the present study, we examined the expression of mature BDNF in the hippocampus to find the possible mechanisms associated with the effects of fLJE on cell proliferation and neuroblast differentiation because stress-induced glucocorticoid regulates BDNF expression $[60,61]$ and BDNF is related to alterations due to psychological stress and synaptic plasticity [62-64]. Genetic deletion of BDNF impairs synaptic plasticity based on long-term potentiation [65], while BDNF supplementation or overexpression significantly ameliorates the impairment in synaptic function $[66,67]$. In addition, several lines of evidence demonstrate that some doublecortin cells expressed the tropomyosin receptor kinase B [68-70]. In the present study, we sacrificed the animals immediately after the last stress session because BDNF levels dynamically change after stress [71]. Physical and psychological stress significantly decreased BDNF levels in the hippocampus in our study. This result is consistent with previous studies that showed acute immobilization and restraint stress reduced BDNF mRNA levels in the dentate gyrus [60,71-73]. In addition, fear conditioning and social isolation decreased mRNA expression in the hippocampus [74,75]. Moreover, Li et al. showed that psychological stress significantly decreased BDNF mRNA levels immediately after stress and that BDNF mRNA levels returned to baseline $2 \mathrm{~h}$ after stress [71]. Administration of fLJE to physically stressed mice significantly increased BDNF expression compared to the FS group. However, we could not observe the changes of BDNF levels in the hippocampus of psychologically stressed group after fLJE treatment. In a model of memory deficit induced by trimethyltin treatment, administration of $50-200 \mathrm{mg} / \mathrm{kg}$ fLJE recovered the 
reduction in BDNF expression in the hippocampus [40]. Fucoidan also ameliorated the reduction in BDNF expression in the hippocampus [73].

In the present study, we also observed pCREB immunoreactivity in the dentate gyrus, because CREB is believed to be one of the components of the BDNF downstream pathway [76,77]. Moreover, the phosphorylation of CREB at Ser133 facilitates neuronal regeneration and repair [78-80]. In the present study, we observed a significant reduction in pCREB-positive nuclei after physical and psychological stress in mice. Consistent with the changes in BDNF expression in the hippocampus, the number of pCREB-positive nuclei in the fLJE-FS group was significantly increased compared to the FS group, while pCREB was moderately (not significantly) increased in fLJE-NFS group compared to the NFS group.

Enhanced neurogenesis by environmental enrichment, electroacupuncture, and fluoxetine treatment significantly improved neurogenesis and the expression of BDNF and PCREB in the hippocampus [81,82]. In contrast, intracerebroventricular infusion of K252a, a Trk antagonist, blocked the enhanced neurogenesis in the dentate gyrus [81,82] and enhanced expression of pCREB [82]. Administration of fLJE mitigated the reduction in PCREB immunoreactive cells in the hippocampus after trimethytin treatment [40]. However, Park et al. only observed BDNF and pCREB immunoreactivity in the hippocampal CA1 and CA3 regions, but not in the dentate gyrus [40]. In the present study, we observed the effects of fLJE on cell proliferation and neuroblast differentiation in the hippocampus of physically stressed mice, not psychologically stressed mice, in relation to the expression of BDNF and PCREB.

Recently, many studies have been conducted to elucidate the active ingredients in LJE. The LJE extract contains alginates, fucoidan, laminarin, and fucoxanthin with anti-viral, anti-tumor, anti-hyperglycemic, and anti-coagulation activities $[26,83,84]$. In the present study, we observed the dramatic increases of reducing sugar contents after fermentation of LJE and the total phenolic compounds were also significantly increased. The fermentation of LJE by A. oryzae may cause disruption of seaweed cell wall and increased phenolic compounds molecules because $A$. oryzae contains high amounts of catalytic enzymes [85]. This fermentation may increase the phenolic compounds to activate the cell proliferation and neuroblast differentiation in the dentate gyrus. Brain has blood-brain barrier, which is a unique structure to limit the delivery of active compounds into brain. Many studies have been attempted to find the possible molecules to cross the blood-brain barrier in LJE and fLJE. Fucoidan, an abundant compound derived from marine brown algae, has anti-depressant effects and ameliorated the reduction of BDNF-dependent synaptic plasticity in the hippocampus [86]. In addition, fucoidan from Ecklonia cava showed improvement from learning and memory impairment induced by trimethyltin treatment [87]. In the memory deficit model induced by D-galactose treatment, secondary metabolites of Galactomyces geotrichum from Laminaria japonica shows positive effects on cognitive function [88]. However, the study has limitation because we did not observe the possible polyphenolic compounds or fucoidan to cross the blood-brain barrier and to ameliorate the stress-induced reduction of hippocampal neurogenesis and BDNF-pCREB signaling.

In conclusion, physical stress, not psychological stress, significantly increases plasma corticosterone levels. However, physical, not psychological, stress decreases the number of proliferating cells, neuroblasts, pCREB-positive nuclei, and BDNF expression in the dentate gyrus. Administration of fLJE significantly ameliorates the changes occurring in physically, not psychologically, stressed mice. These results suggest that fLJE can be used as a functional food to improve the physical, not psychological, stress induced reduction in hippocampal neurogenesis by increasing BDNF and pCREB levels when consumed equivalent dosage $(486 \mathrm{mg})$ converted in human based on the equation described by Nair and Jacob [89]. 


\section{Materials and Methods}

\subsection{Preparation of $f L J E$}

L. japonica was obtained from the local market in Jeju and we freeze-dried it to ferment with Aspergillus oryzae at $35 \pm 1{ }^{\circ} \mathrm{C}$ for $72 \mathrm{~h}$. Thereafter, the fermented L. japonica was extracted with water-extraction method. Ethanol is added to extract solution and centrifuged to separate the ethanol-soluble fraction, which is lyophilized and store at $-80^{\circ} \mathrm{C}$ until utilization.

\subsection{Total and Reducing Sugar Contents}

Total sugar in LJE were measured spectrophotometrically before and after fermentation by phenol-sulfuric method. In addition, the reducing sugar contents were analyzed by enzymatic methods using 3,5-dinitrosalicylic acid method described by Marsden et al. [90].

\subsection{Total Phenolic Assay}

Total phenols in the fLJE were measured by using Folin-Ciocalteu reagent. In brief, the mixture of $0.5 \mathrm{~mL}$ of fLJE and $0.1 \mathrm{~mL}$ of Folin-Ciocalteu reagent were made and $2.5 \mathrm{~mL}$ of saturated $\mathrm{Na}_{2} \mathrm{CO}_{3}(75 \mathrm{~g} / \mathrm{L})$ was added for $30 \mathrm{~min}$ at $25^{\circ} \mathrm{C}$. The absorbance was measured at $760 \mathrm{~nm}$ using spectrophotometer. The concentration of the total phenolic compounds was calculated as mg of gallic acid equivalent by using an equation obtained from gallic acid calibration curve.

\subsection{Experimental Animals}

Sixty-nine male Institute Cancer Research (ICR, CD-1) outbred mice ( 5 weeks of age) were obtained from Orient Bio (Seongnam, South Korea) and the mice were housed in a conventional facility at Seoul National University and experimental protocols were approved by the Institutional Animal Care and Use Committee of Seoul National University (SNU-120103-10).

\subsection{Experimental Groups}

The animals were divided into 5 groups as follows: control $(n=15)$, physical stress (foot-shock, FS) group $(n=15)$, psychological stress (non-foot-shock, NFS) group $(n=12), 50 \mathrm{mg} / \mathrm{kg}$ fLJE-treated FS (fLJE-FS) group $(n=15), 50 \mathrm{mg} / \mathrm{kg}$ fLJE-treated NFS (fLJE-NFS) group $(n=12)$. Six-week-old mice received an oral administration of $100 \mathrm{mg} / \mathrm{kg}$ fLJE once a day for 21 days because neuroblasts/immature neurons are expressed in DCX from day 1 to day 28 of birth in cells [91,92]. The dosage of fLJE was chosen because Reid et al. showed cognitive improvements at a dose of $50 \mathrm{mg} / \mathrm{kg}$ of fLJE [39].

\subsection{Induction of Physical or Psychological Stress}

On day 19 of the treatment, physical or psychological stress was induced using a communication box as described by Li et al. [93]. The communication box consisted of an open box $(48 \mathrm{~cm} \times 48 \mathrm{~cm} \times 50 \mathrm{~cm})$ with transparent acryl as shown in Figure 1. Stainless steel rods placed on the floor to administer electrical shocks at the center and in the four corners (physical stress compartment) and a plastic insulator set at the others (psychological stress compartment). Mice were randomly divided into FS and NSF group and placed in each compartment for adaptation to the apparatus $30 \mathrm{~min}$ prior to the induction of stress. Five ( $n=30$ in total) of the nine mice ( $n=54$ in total) located in physical stress compartment received a $0.3-\mathrm{mA}$ electric current for $10 \mathrm{~s}$. The electric shock was delivered randomly for an average of 30 times in 60 min using a shock generator (Jeung Do Bio \& Plant Co., LTD, Seoul, Korea) between 14:00 and 15:00 for three consecutive days. The other four (NFS) mice $(n=24$ in total) experienced the stimuli (visual, auditory and olfactory sensation) from physically stressed mice. After last electric shock, mice returned to its original position on the cage and were provided with both water and food at libitum. The control mice $(n=15)$ were placed in electric-free compartment with 
electric stimulation in the absence of the physically stressed mice. All mice were carefully handled during the experiment to minimize the stress described by Gouveia and Hurst [94].

\subsection{Blood Sampling and Measurements of Plasma Corticosterone Levels}

Following the physical and psychological stress episodes, animals ( $n=12$ or 15 in each group) were deeply anesthetized with a mixture of alfaxalone (Alfaxan, $75 \mathrm{mg} / \mathrm{kg}$; Careside, Seongnam, Korea) and xylazine (10 mg/kg; Bayer Korea, Seoul, Korea), and blood samples were obtained from cardiac puncture in each animal. The plasma was separated from the blood and the plasma corticosterone levels were measure as described in a previous study [95].

\subsection{Tissue Processing for Histology and Immunohistochemical Staining}

After blood sampling, the animals were perfused transcardially and brain sample was dissected as described previously [96,97]. Thirty micrometer brain sections were cut between 1.82 and $2.30 \mathrm{~mm}$ caudal to the bregma, as defined by a mouse atlas [98] and immunohistochemical staining for Ki67, DCX, and phosphorylated cAMP response element binding protein at Ser133 (pCREB) was conducted as described in a previous study [96]. Briefly, the tissue sections located at a distance of $120 \mu \mathrm{m}$ from each other were selected and incubated with rabbit anti-Ki67 antibody (1:1000; Abcam, Cambridge, UK), rabbit anti-DCX (1:5000; Abcam), or rabbit anti-pCREB (1:400; Cell Signaling Technology, Inc., Beverly, MA, USA) at $25^{\circ} \mathrm{C}$ overnight. The sections were sequentially treated with biotinylated goat anti-rabbit IgG and a streptavidin-peroxidase complex (1:200; Vector, Burlingame, CA, USA) for $2 \mathrm{~h}$ at $25^{\circ} \mathrm{C}$. The sections were visualized by reacting 3,3'-diaminobenzidine tetrachloride (Sigma) in $0.1 \mathrm{M}$ Tris- $\mathrm{HCl}$ buffer ( $\mathrm{pH}$ 7.2). The specificity of antibodies used in the present study was established by substitution of goat anti-rabbit IgG to isotype control IgG (Abcam) [99]. Cancer tissues from xenograft tissue were also used for Ki67 as a positive control. Immunoreactive structure disappeared completely in dentate gyrus and Ki67 immunoreactive cells are abundantly detected in cancer tissues (Figure S1).

\subsection{Western Blot and Quantitative Real-Time Polymerase Chain Reaction (PCR)}

Following the last physical and psychological stress episode, the animals ( $n=6-7$ in each group) were immediately sacrificed using with a mixture of alfaxalone and xylazine. After subsequent decapitation, the 500- $\mu \mathrm{m}$-thick hippocampal sections were used for western blot and real-time PCR study as described in a previous study [87]. Briefly, the protein-transferred membrane was sequentially incubated with rabbit anti-BDNF (diluted 1:5000, Abcam), CREB (1:1000; Cell Signaling Technology, Inc., Beverly, MA, USA), or pCREB (1:1000; Cell Signaling Technology, Inc.), peroxidase-conjugated goat anti-rabbit IgG (1:5000, SantaCruz Biotechnology, Santa Cruz, CA, USA), and an ECL chemiluminescent kit (Pierce; Thermo Fisher Scientific, Inc., Waltham, MA, USA). For quantitative real-time PCR analyses, the hippocampal tissues were processed as described by Cao et al. [100] and primers of BNDF were used as described in the previous study [97].

\subsection{Data Analysis}

DCX immunoreactivity was quantitatively analyzed using ImageJ software v. 1.50 (National Institutes of Health, Bethesda, MD, USA) as described in previous studies $[15,86,87]$. Digital image of DCX immunoreactive structures was converted into gray, which has a resolution with 0-255 and the gray intensity and pixel number was measured. Intensity of DCX immunoreactivity was evaluated by determining the relative optical density (ROD), which was obtained after transformation of the mean gray level using the following formula: $\mathrm{ROD}=\log _{10}$ (256/mean gray level).

The number of Ki67- and pCREB-immunoreactive nuclei was counted with OPTIMAS software (version 6.5; CyberMetrics ${ }^{\circledR}$ Corporation, Phoenix, AZ, USA) as described in a previous study [96]. 


\subsection{Statistical Analysis}

Data was analyzed statistically by one-way analysis of variance followed by Bonferroni's post-hoc test using GraphPad Prism 5.01 software (GraphPad Software, Inc., La Jolla, CA, USA) and the results were considered to be statistically significant if $p<0.05$.

Supplementary Materials: The following are available online at http://www.mdpi.com/1660-3397/18/12/587/s1, Figure S1: Control staining for antibodies used in this study.

Author Contributions: Conceptualization, H.Y.J. and I.K.H.; methodology, H.Y.J., W.K., H.J.K., and K.R.H.; data curation, H.Y.J., D.Y.Y. and S.M.N.; writing-original draft preparation, H.Y.J.; writing-review and editing, S.S.Y., J.H.C., D.W.K., Y.S.Y. and I.K.H. All authors have read and agreed to the published version of the manuscript.

Funding: This work was supported by the National Research Foundation of Korea (NRF) grant funded by the Korea government (MSIP) (No. NRF-2016R1A2B4009156). In addition, this study was partially supported by the Research Institute for Veterinary Science of Seoul National University.

Conflicts of Interest: The authors declare no conflict of interest.

\section{References}

1. Rubin, R.D.; Watson, P.D.; Duff, M.C.; Cohen, N.J. The role of the hippocampus in flexible cognition and social behavior. Front. Hum. Neurosci. 2014, 8, 742. [CrossRef]

2. White, B.C.; Grossman, L.I.; O'Neil, B.J.; DeGracia, D.J.; Neumar, R.W.; Rafols, J.A.; Krause, G.S. Global brain ischemia and reperfusion. Ann. Emerg. Med. 1996, 27, 588-594. [CrossRef]

3. Ondrejcak, T.; Klyubin, I.; Hu, N.W.; Barry, A.E.; Cullen, W.K.; Rowan, M.J. Alzheimer's disease amyloid beta-protein and synaptic function. Neuromol. Med. 2010, 12, 13-26. [CrossRef] [PubMed]

4. Eriksson, P.S.; Perfilieva, E.; Björk-Eriksson, T.; Alborn, A.M.; Nordborg, C.; Peterson, D.A.; Gage, F.H. Neurogenesis in the adult human hippocampus. Nat. Med. 1998, 4, 1313-1317. [CrossRef] [PubMed]

5. Alam, M.J.; Kitamura, T.; Saitoh, Y.; Ohkawa, N.; Kondo, T.; Inokuchi, K. Adult neurogenesis conserves hippocampal memory capacity. J. Neurosci. 2018, 38, 6854-6863. [CrossRef] [PubMed]

6. Braun, S.M.; Jessberger, S. Adult neurogenesis and its role in neuropsychiatric disease, brain repair and normal brain function. Neuropathol. Appl. Neurobiol. 2014, 40, 3-12. [CrossRef] [PubMed]

7. Gu, Y.; Arruda-Carvalho, M.; Wang, J.; Janoschka, S.R.; Josselyn, S.A.; Frankland, P.W.; Ge, S. Optical controlling reveals time-dependent roles for adult-born dentate granule cells. Nat. Neurosci. 2012, 15, 1700-1706. [CrossRef]

8. Kee, N.; Teixeira, C.M.; Wang, A.H.; Frankland, P.W. Preferential incorporation of adult-generated granule cells into spatial memory networks in the dentate gyrus. Nat. Neurosci. 2007, 10, 355-362. [CrossRef]

9. Richetin, K.; Leclerc, C.; Toni, N.; Gallopin, T.; Pech, S.; Roybon, L.; Rampon, C. Genetic manipulation of adult-born hippocampal neurons rescues memory in a mouse model of Alzheimer's disease. Brain 2015, 138, 440-455. [CrossRef]

10. Dard, R.F.; Dahan, L.; Rampon, C. Targeting hippocampal adult neurogenesis using transcription factors to reduce Alzheimer's disease-associated memory impairments. Hippocampus 2019, 29, 579-586. [CrossRef]

11. Pereira-Caixeta, A.R.; Guarnieri, L.O.; Medeiros, D.C.; Mendes, E.M.A.M.; Ladeira, L.C.D.; Pereira, M.T.; Moraes, M.F.D.; Pereira, G.S. Inhibiting constitutive neurogenesis compromises long-term social recognition memory. Neurobiol. Learn. Mem. 2018, 155, 92-103. [CrossRef] [PubMed]

12. Schoenfeld, T.J.; Gould, E. Stress, stress hormones, and adult neurogenesis. Exp. Neurol. 2012, 233, 12-21. [CrossRef]

13. Belanoff, J.K.; Gross, K.; Yager, A.; Schatzberg, A.F. Corticosteroids and cognition. J. Psychiatr. Res. 2001, 35, 127-145. [CrossRef]

14. Roozendaal, B. 1999 Curt P. Richter award. Glucocorticoids and the regulation of memory consolidation. Psychoneuroendocrinology 2000, 25, 213-238. [CrossRef]

15. Cinini, S.M.; Barnabe, G.F.; Galvão-Coelho, N.; de Medeiros, M.A.; Perez-Mendes, P.; Sousa, M.B.; Covolan, L.; Mello, L.E. Social isolation disrupts hippocampal neurogenesis in young non-human primates. Front. Neurosci. 2014, 8, 45. [CrossRef] 
16. Shields, G.S.; McCullough, A.M.; Ritchey, M.; Ranganath, C.; Yonelinas, A.P. Stress and the medial temporal lobe at rest: Functional connectivity is associated with both memory and cortisol. Psychoneuroendocrinology 2019, 106, 138-146. [CrossRef] [PubMed]

17. Lee, C.H.; Yoo, D.Y.; Park, O.K.; Park, J.H.; Yi, S.S.; Yoon, Y.S.; Won, M.H.; Hwang, I.K. Effects of adrenalectomy and replacement therapy of corticosterone on cell proliferation and neuroblast differentiation in the rat dentate gyrus. Neurochem. Res. 2011, 36, 1767-1775. [CrossRef]

18. Fernández, M.S.; de Olmos, S.; Nizhnikov, M.E.; Pautassi, R.M. Restraint stress exacerbates cell degeneration induced by acute binge ethanol in the adolescent, but not in the adult or middle-aged, brain. Behav. Brain Res. 2019, 364, 317-327. [CrossRef]

19. Jafari, Z.; Okuma, M.; Karem, H.; Mehla, J.; Kolb, B.E.; Mohajerani, M.H. Prenatal noise stress aggravates cognitive decline and the onset and progression of beta amyloid pathology in a mouse model of Alzheimer's disease. Neurobiol. Aging 2019, 77, 66-86. [CrossRef]

20. Dodiya, H.B.; Forsyth, C.B.; Voigt, R.M.; Engen, P.A.; Patel, J.; Shaikh, M.; Green, S.J.; Naqib, A.; Roy, A.; Kordower, J.H.; et al. Chronic stress-induced gut dysfunction exacerbates Parkinson's disease phenotype and pathology in a rotenone-induced mouse model of Parkinson's disease. Neurobiol. Dis. 2020, 135, 104352. [CrossRef]

21. Murata, Y.; Narisawa, Y.; Shimono, R.; Ohmori, H.; Mori, M.; Ohe, K.; Mine, K.; Enjoji, M. A high fat diet-induced decrease in hippocampal newly-born neurons of male mice is exacerbated by mild psychological stress using a Communication Box. J. Affect. Disord. 2017, 209, 209-216. [CrossRef] [PubMed]

22. Odagiri, K.; Abe, H.; Kawagoe, C.; Takeda, R.; Ikeda, T.; Matsuo, H.; Nonaka, H.; Ebihara, K.; Nishimori, T.; Ishizuka, Y.; et al. Psychological prenatal stress reduced the number of BrdU immunopositive cells in the dorsal hippocampus without affecting the open field behavior of male and female rats at one month of age. Neurosci. Lett. 2008, 446, 25-29. [CrossRef] [PubMed]

23. Ning, C.; Wang, H.D.; Gao, R.; Chang, Y.C.; Hu, F.; Meng, X.; Huang, S.Y. Marine-derived protein kinase inhibitors for neuroinflammatory diseases. Biomed. Eng. Online 2018, 17, 46. [CrossRef] [PubMed]

24. Hannan, M.A.; Dash, R.; Haque, M.N.; Mohibbullah, M.; Sohag, A.A.M.; Rahman, M.A.; Uddin, M.J.; Alam, M.; Moon, I.S. Neuroprotective potentials of marine algae and their bioactive metabolites: Pharmacological insights and therapeutic advances. Mar. Drugs 2020, 18, 347. [CrossRef]

25. Schepers, M.; Martens, N.; Tiane, A.; Vanbrabant, K.; Liu, H.B.; Lütjohann, D.; Mulder, M.; Vanmierlo, T. Edible seaweed-derived constituents: An undisclosed source of neuroprotective compounds. Neural Regen. Res. 2020, 15, 790-795. [PubMed]

26. Shirosaki, M.; Koyama, T. Laminaria japonica as a food for the prevention of obesity and diabetes. Adv. Food Nutr. Res. 2011, 64, 199-212. [PubMed]

27. Israel, I.; Fluri, F.; Schadt, F.; Buck, A.K.; Samnick, S. Positron emission tomography and autoradiography imaging of P-selectin activation using 68Ga-fucoidan in photothrombotic stroke. Curr. Neurovasc. Res. 2018, 15, 55-62. [CrossRef]

28. Kim, H.; Ahn, J.H.; Song, M.; Kim, D.W.; Lee, T.K.; Lee, J.C.; Kim, Y.M.; Kim, J.D.; Cho, J.H.; Hwang, I.K.; et al. Pretreated fucoidan confers neuroprotection against transient global cerebral ischemic injury in the gerbil hippocampal CA1 area via reducing of glial cell activation and oxidative stress. Biomed. Pharmacother. 2019, 109, 1718-1727. [CrossRef]

29. Wang, T.; Zhu, M.; He, Z.Z. Low-molecular-weight fucoidan attenuates mitochondrial dysfunction and improves neurological outcome after traumatic brain injury in aged mice: Involvement of Sirt3. Cell. Mol. Neurobiol. 2016, 36, 1257-1268. [CrossRef]

30. Zhang, L.; Hao, J.; Zheng, Y.; Su, R.; Liao, Y.; Gong, X.; Liu, L.; Wang, X. Fucoidan protects dopaminergic neurons by enhancing the mitochondrial function in a rotenone-induced rat model of Parkinson's disease. Aging Dis. 2018, 9, 590-604. [CrossRef]

31. Caltagirone, C.; Ferrannini, L.; Marchionni, N.; Nappi, G.; Scapagnini, G.; Trabucchi, M. The potential protective effect of tramiprosate (homotaurine) against Alzheimer's disease: A review. Aging Clin. Exp. Res. 2012, 24, 580-587. [PubMed]

32. Kim, I.H.; Yoo, K.Y.; Park, J.H.; Yan, B.C.; Ahn, J.H.; Lee, J.C.; Kwon, H.M.; Kim, J.D.; Kim, Y.M.; You, S.G.; et al. Comparison of neuroprotective effects of extract and fractions from Agarum clathratum against experimentally induced transient cerebral ischemic damage. Pharm. Biol. 2014, 52, 335-343. [CrossRef] [PubMed] 
33. Pabon, M.M.; Jernberg, J.N.; Morganti, J.; Contreras, J.; Hudson, C.E.; Klein, R.L.; Bickford, P.C. A spirulina-enhanced diet provides neuroprotection in an $\alpha$-synuclein model of Parkinson's disease. PLoS ONE 2012, 7, e45256. [CrossRef] [PubMed]

34. Souza, R.B.; Frota, A.F.; Sousa, R.S.; Cezario, N.A.; Santos, T.B.; Souza, L.M.; Coura, C.O.; Monteiro, V.S.; Cristino Filho, G.; Vasconcelos, S.M.; et al. Neuroprotective effects of sulphated agaran from marine Alga Gracilaria cornea in rat 6-hydroxydopamine Parkinson's disease model: Behavioural, neurochemical and transcriptional alterations. Basic Clin. Pharmacol. Toxicol. 2017, 120, 159-170. [CrossRef]

35. Katina, K.; Laitila, A.; Juvonen, R.; Liukkonen, K.H.; Kariluoto, S.; Piironen, V.; Landberg, R.; Aman, P.; Poutanen, K. Bran fermentation as a means to enhance technological properties and bioactivity of rye. Food Microbiol. 2007, 24, 175-186. [CrossRef]

36. Wang, G.H.; Lin, Y.M.; Kuo, J.T.; Lin, C.P.; Chang, C.F.; Hsieh, M.C.; Cheng, C.Y.; Chung, Y.C. Comparison of biofunctional activity of Asparagus cochinchinensis (Lour.) Merr. Extract before and after fermentation with Aspergillus oryzae. J. Biosci. Bioeng. 2019, 127, 59-65. [CrossRef]

37. Lin, H.T.V.; Lu, W.-J.; Tsai, G.-J.; Chou, C.-T.; Hsiao, H.-I.; Hwang, P.-A. Enhanced anti-inflammatory activity of brown seaweed Laminaria japonica by fermentation using Bacillus subtilis. Process Biochem. 2016, 51, 1945-1953. [CrossRef]

38. Park, M.J.; Han, J.S. Radical scavenging and antioxidant activities of fermented Laminaria japonica extracts. J. Food Sci. Nutr. 2006, 11, 10-16. [CrossRef]

39. Reid, S.N.S.; Ryu, J.K.; Kim, Y.; Jeon, B.H. GABA-enriched fermented Laminaria japonica improves cognitive impairment and neuroplasticity in scopolamine- and ethanol-induced dementia model mice. Nutr. Res. Pract. 2018, 12, 199-207. [CrossRef]

40. Park, H.J.; Lee, M.S.; Shim, H.S.; Lee, G.R.; Chung, S.Y.; Kang, Y.M.; Lee, B.J.; Seo, Y.B.; Kim, K.S.; Shim, I. Fermented Saccharina japonica (Phaeophyta) improves neuritogenic activity and TMT-induced cognitive deficits in rats. Algae 2016, 31, 73-84. [CrossRef]

41. Esch, T.; Stefano, G.B.; Fricchione, G.L.; Benson, H. The role of stress in neurodegenerative diseases and mental disorders. Neuro Endocrinol. Lett. 2002, 23, 199-208. [PubMed]

42. Huether, G.; Doering, S.; Rüger, U.; Rüther, E.; Schüssler, G. The stress-reaction process and the adaptive modification and reorganization of neuronal networks. Psychiatry Res. 1999, 87, 83-95. [CrossRef]

43. McEwen, B.S. Allostasis, allostatic load, and the aging nervous system: Role of excitatory amino acids and excitotoxicity. Neurochem. Res. 2000, 25, 1219-1231. [CrossRef] [PubMed]

44. Chrousos, G.P.; Gold, P.W. The concepts of stress and stress system disorders. Overview of physical and behavioral homeostasis. JAMA 1992, 267, 1244-1252. [CrossRef] [PubMed]

45. Jafari, M.; Salehi, M.; Zardooz, H.; Rostamkhani, F. Response of liver antioxidant defense system to acute and chronic physical and psychological stresses in male rats. EXCLI J. 2014, 13, 161-171.

46. Campbell, T.; Lin, S.; DeVries, C.; Lambert, K. Coping strategies in male and female rats exposed to multiple stressors. Physiol. Behav. 2003, 78, 495-504. [CrossRef]

47. Pyter, L.M.; Kelly, S.D.; Harrell, C.S.; Neigh, G.N. Sex differences in the effects of adolescent stress on adult brain inflammatory markers in rats. Brain Behav. Immun. 2013, 30, 88-94. [CrossRef]

48. Takahashi, A.; Chung, J.R.; Zhang, S.; Zhang, H.; Grossman, Y.; Aleyasin, H.; Flanigan, M.E.; Pfau, M.L.; Menard, C.; Dumitriu, D.; et al. Establishment of a repeated social defeat stress model in female mice. Sci. Rep. 2017, 7, 12838. [CrossRef]

49. Toledo-Rodriguez, M.; Sandi, C. Stress during adolescence increases novelty seeking and risk-taking behavior in male and female rats. Front. Behav. Neurosci. 2011, 5, 17. [CrossRef]

50. Endo, Y.; Yamauchi, K.; Fueta, Y.; Irie, M. Changes of body temperature and plasma corticosterone level in rats during psychological stress induced by the communication box. Med. Sci. Monit. 2001, 7, 1161-1165.

51. Du Preez, A.; Law, T.; Onorato, D.; Lim, Y.M.; Eiben, P.; Musaelyan, K.; Egeland, M.; Hye, A.; Zunszain, P.A.; Thuret, S.; et al. The type of stress matters: Repeated injection and permanent social isolation stress in male mice have a differential effect on anxiety- and depressive-like behaviours, and associated biological alterations. Transl. Psychiatry 2020, 10, 325. [CrossRef] [PubMed]

52. Hill, A.S.; Sahay, A.; Hen, R. Increasing adult hippocampal neurogenesis is sufficient to reduce anxiety and depression-like behaviors. Neuropsychopharmacology 2015, 40, 2368-2378. [CrossRef] [PubMed]

53. Tsai, C.Y.; Tsai, C.Y.; Arnold, S.J.; Huang, G.J. Ablation of hippocampal neurogenesis in mice impairs the response to stress during the dark cycle. Nat. Commun. 2015, 6, 8373. [CrossRef] [PubMed] 
54. Wu, Y.P.; Gao, H.Y.; Ouyang, S.H.; Kurihara, H.; He, R.R.; Li, Y.F. Predator stress-induced depression is associated with inhibition of hippocampal neurogenesis in adult male mice. Neural Regen. Res. 2019, 14, 298-305.

55. Bath, K.G.; Manzano-Nieves, G.; Goodwill, H. Early life stress accelerates behavioral and neural maturation of the hippocampus in male mice. Horm. Behav. 2016, 82, 64-71. [CrossRef]

56. Hannan, M.A.; Kang, J.Y.; Hong, Y.K.; Lee, H.; Chowdhury, M.T.; Choi, J.S.; Choi, I.S.; Moon, I.S. A brown alga Sargassum fulvellum facilitates neuronal maturation and synaptogenesis. In Vitro Cell. Dev. Biol. Anim. 2012, 48, 535-544. [CrossRef]

57. Mohibbullah, M.; Bhuiyan, M.M.; Hannan, M.A.; Getachew, P.; Hong, Y.K.; Choi, J.S.; Choi, I.S.; Moon, I.S. The edible red alga Porphyra yezoensis promotes neuronal survival and cytoarchitecture in primary hippocampal neurons. Cell. Mol. Neurobiol. 2016, 36, 669-682. [CrossRef]

58. Sasaki, K.; Othman, M.B.; Demura, M.; Watanabe, M.; Isoda, H. Modulation of neurogenesis through the promotion of energy production activity is behind the antidepressant-like effect of colonial green alga, Botryococcus braunii. Front. Physiol. 2017, 8, 900. [CrossRef]

59. Alghazwi, M.; Smid, S.; Karpiniec, S.; Zhang, W. Comparative study on neuroprotective activities of fucoidans from Fucus vesiculosus and Undaria pinnatifida. Int. J. Biol. Macromol. 2019, 122, 255-264. [CrossRef]

60. Smith, M.A.; Makino, S.; Kvetnansky, R.; Post, R.M. Stress and glucocorticoids affect the expression of brain-derived neurotrophic factor and neurotrophin-3 mRNAs in the hippocampus. J. Neurosci. 1995, 15, 1768-1777. [CrossRef]

61. Suri, D.; Vaidya, V.A. Glucocorticoid regulation of brain-derived neurotrophic factor: Relevance to hippocampal structural and functional plasticity. Neuroscience 2013, 239, 196-213. [CrossRef] [PubMed]

62. Lu, B. BDNF and activity-dependent synaptic modulation. Learn. Mem. 2003, 10, 86-98. [CrossRef] [PubMed]

63. Poo, M.M. Neurotrophins as synaptic modulators. Nat. Rev. Neurosci. 2001, 2, 24-32. [CrossRef] [PubMed]

64. Schinder, A.F.; Poo, M. The neurotrophin hypothesis for synaptic plasticity. Trends Neurosci. 2000, 23, 639-645. [CrossRef]

65. Figurov, A.; Pozzo-Miller, L.D.; Olafsson, P.; Wang, T.; Lu, B. Regulation of synaptic responses to high-frequency stimulation and LTP by neurotrophins in the hippocampus. Nature 1996, 381, 706-709. [CrossRef]

66. Korte, M.; Carroll, P.; Wolf, E.; Brem, G.; Thoenen, H.; Bonhoeffer, T. Hippocampal long-term potentiation is impaired in mice lacking brain-derived neurotrophic factor. Proc. Natl. Acad. Sci. USA 1995, 92, 8856-8860. [CrossRef]

67. Patterson, S.L.; Abel, T.; Deuel, T.A.; Martin, K.C.; Rose, J.C.; Kandel, E.R. Recombinant BDNF rescues deficits in basal synaptic transmission and hippocampal LTP in BDNF knockout mice. Neuron 1996, 16, 1137-1145. [CrossRef]

68. Bergami, M.; Rimondini, R.; Santi, S.; Blum, R.; Götz, M.; Canossa, M. Deletion of TrkB in adult progenitors alters newborn neuron integration into hippocampal circuits and increases anxiety-like behavior. Proc. Natl. Acad. Sci. USA 2008, 105, 15570-15575. [CrossRef]

69. Jeanneteau, F.; Garabedian, M.J.; Chao, M.V. Activation of Trk neurotrophin receptors by glucocorticoids provides a neuroprotective effect. Proc. Natl. Acad. Sci. USA 2008, 105, 4862-4867. [CrossRef]

70. Lafenêtre, P.; Leske, O.; Ma-Högemeie, Z.; Haghikia, A.; Bichler, Z.; Wahle, P.; Heumann, R. Exercise can rescue recognition memory impairment in a model with reduced adult hippocampal neurogenesis. Front. Behav. Neurosci. 2010, 3, 34. [CrossRef]

71. Li, G.; Wang, Y.; Yan, M.; Ma, H.; Gao, Y.; Li, Z.; Li, C.; Tian, H.; Zhuo, C. Time-dependent co-relation of BDNF and CREB mRNAs in adult rat brains following acute psychological stress in the communication box paradigm. Neurosci. Lett. 2016, 624, 34-41. [CrossRef] [PubMed]

72. Adlard, P.A.; Cotman, C.W. Voluntary exercise protects against stress-induced decreases in brain-derived neurotrophic factor protein expression. Neuroscience 2004, 124, 985-992. [CrossRef] [PubMed]

73. Lee, B.; Shim, I.; Lee, H.; Hahm, D.H. Fucoidan prevents depression-like behavior in rats exposed to repeated restraint stress. J. Nat. Med. 2013, 67, 534-544. [CrossRef] [PubMed]

74. Barrientos, R.M.; Sprunger, D.B.; Campeau, S.; Higgins, E.A.; Watkins, L.R.; Rudy, J.W.; Maier, S.F. Brain-derived neurotrophic factor mRNA downregulation produced by social isolation is blocked by intrahippocampal interleukin-1 receptor antagonist. Neuroscience 2003, 121, 847-853. [CrossRef] 
75. Rasmusson, A.M.; Shi, L.; Duman, R. Downregulation of BDNF mRNA in the hippocampal dentate gyrus after re-exposure to cues previously associated with footshock. Neuropsychopharmacology 2002, 27, 133-142. [CrossRef]

76. Finkbeiner, S. Calcium regulation of the brain-derived neurotrophic factor gene. Cell. Mol. Life Sci. 2000, 57, 394-401. [CrossRef]

77. Otten, U.; März, P.; Heese, K.; Hock, C.; Kunz, D.; Rose-John, S. Cytokines and neurotrophins interact in normal and diseased states. Ann. N. Y. Acad. Sci. 2000, 917, 322-330. [CrossRef]

78. Arthur-Farraj, P.J.; Latouche, M.; Wilton, D.K.; Quintes, S.; Chabrol, E.; Banerjee, A.; Woodhoo, A.; Jenkins, B.; Rahman, M.; Turmaine, M.; et al. c-Jun reprograms Schwann cells of injured nerves to generate a repair cell essential for regeneration. Neuron 2012, 75, 633-647. [CrossRef]

79. Harris, N.G.; Nogueira, M.S.; Verley, D.R.; Sutton, R.L. Chondroitinase enhances cortical map plasticity and increases functionally active sprouting axons after brain injury. J. Neurotrauma 2013, 30, 1257-1269. [CrossRef]

80. Li, Q.; Wu, D.; Li, R.; Zhu, X.; Cui, S. Valproic acid protects neurons and promotes neuronal regeneration after brachial plexus avulsion. Neural Regen. Res. 2013, 8, 2838-2848.

81. Hwang, I.K.; Chung, J.Y.; Yoo, D.Y.; Yi, S.S.; Youn, H.Y.; Seong, J.K.; Yoon, Y.S. Effects of electroacupuncture at Zusanli and Baihui on brain-derived neurotrophic factor and cyclic AMP response element-binding protein in the hippocampal dentate gyrus. J. Vet. Med. Sci. 2010, 72, 1431-1436. [CrossRef] [PubMed]

82. Pinnock, S.B.; Blake, A.M.; Platt, N.J.; Herbert, J. The roles of BDNF, pCREB and Wnt3a in the latent period preceding activation of progenitor cell mitosis in the adult dentate gyrus by fluoxetine. PLoS ONE 2010, 5, e13652. [CrossRef] [PubMed]

83. Cao, Y.G.; Hao, Y.; Li, Z.H.; Liu, S.T.; Wang, L.X. Antiviral activity of polysaccharide extract from Laminaria japonica against respiratory syncytial virus. Biomed. Pharmacother. 2016, 84, 1705-1710. [CrossRef] [PubMed]

84. Ming, J.X.; Wang, Z.C.; Huang, Y.; Ohishi, H.; Wu, R.J.; Shao, Y.; Wang, H.; Qin, M.Y.; Wu, Z.L.; Li, Y.Y.; et al. Fucoxanthin extracted from Laminaria Japonica inhibits metastasis and enhances the sensitivity of lung cancer to Gefitinib. J. Ethnopharmacol. 2020, 265, 113302. [CrossRef] [PubMed]

85. Park, H.S.; Jun, S.C.; Han, K.H.; Hong, S.B.; Yu, J.H. Diversity, application, and synthetic biology of industrially important Aspergillus fungi. Adv. Appl. Microbiol. 2017, 100, 161-202. [PubMed]

86. Li, M.; Sun, X.; Li, Q.; Li, Y.; Luo, C.; Huang, H.; Chen, J.; Gong, C.; Li, Y.; Zheng, Y.; et al. Fucoidan exerts antidepressant-like effects in mice via regulating the stability of surface AMPARs. Biochem. Biophys. Res. Commun. 2020, 521, 318-325. [CrossRef] [PubMed]

87. Park, S.K.; Kang, J.Y.; Kim, J.M.; Yoo, S.K.; Han, H.J.; Chung, D.H.; Kim, D.O.; Kim, G.H.; Heo, H.J. Fucoidan-rich substances from Ecklonia cava improve trimethyltin-induced cognitive dysfunction via down-regulation of amyloid $\beta$ production/Tau hyperphosphorylation. Mar. Drugs 2019, 17, 591. [CrossRef]

88. Wang, F.; Wang, F.; Chen, T. Secondary metabolites of Galactomyces geotrichum from Laminaria japonica ameliorate cognitive deficits and brain oxidative stress in D-galactose induced Alzheimer's disease mouse model. Nat. Prod. Res. 2020, 15, 1-6. [CrossRef]

89. Nair, A.B.; Jacob, S. A simple practice guide for dose conversion between animals and human. J. Basic Clin. Pharm. 2016, 7, 27-31. [CrossRef]

90. Marsden, W.L.; Gray, P.P.; Nippard, G.J.; Quinlan, M.R. Evaluation of the DNS method for analysing lignocellulosic hydrolysates. J. Chem. Tech. Biotechnol. 1982, 32, 1016-1022. [CrossRef]

91. Brown, J.P.; Couillard-Després, S.; Cooper-Kuhn, C.M.; Winkler, J.; Aigner, L.; Kuhn, H.G. Transient expression of doublecortin during adult neurogenesis. J. Comp. Neurol. 2003, 467, 1-10. [CrossRef] [PubMed]

92. Couillard-Despres, S.; Winner, B.; Schaubeck, S.; Aigner, R.; Vroemen, M.; Weidner, N.; Bogdahn, U.; Winkler, J.; Kuhn, H.G.; Aigner, L. Doublecortin expression levels in adult brain reflect neurogenesis. Eur. J. Neurosci. 2005, 21, 1-14. [CrossRef] [PubMed]

93. Li, Q.; Liang, Z.; Nakadai, A.; Kawada, T. Effect of electric foot shock and psychological stress on activities of murine splenic natural killer and lymphokine-activated killer cells, cytotoxic T lymphocytes, natural killer receptors and mRNA transcripts for granzymes and perforin. Stress 2005, 8, 107-116. [CrossRef] [PubMed]

94. Gouveia, K.; Hurst, J.L. Improving the practicality of using non-aversive handling methods to reduce background stress and anxiety in laboratory mice. Sci. Rep. 2019, 9, 20305. [CrossRef] [PubMed] 
95. Nam, S.M.; Choi, J.H.; Yoo, D.Y.; Kim, W.; Jung, H.Y.; Kim, J.W.; Kang, S.Y.; Park, J.; Kim, D.W.; Kim, W.J.; et al. Valeriana officinalis extract and its main component, valerenic acid, ameliorate D-galactose-induced reductions in memory, cell proliferation, and neuroblast differentiation by reducing corticosterone levels and lipid peroxidation. Exp. Gerontol. 2013, 48, 1369-1377. [CrossRef]

96. Jung, H.Y.; Kwon, H.J.; Kim, W.; Nam, S.M.; Kim, J.W.; Hahn, K.R.; Yoo, D.Y.; Won, M.H.; Yoon, Y.S.; Kim, D.W.; et al. Phosphoglycerate mutase 1 promotes cell proliferation and neuroblast differentiation in the dentate gyrus by facilitating the phosphorylation of cAMP response element-binding protein. Neurochem. Res. 2019, 44, 323-332. [CrossRef] [PubMed]

97. Yoo, D.Y.; Cho, S.B.; Jung, H.Y.; Kim, W.; Nam, S.M.; Kim, J.W.; Moon, S.M.; Yoon, Y.S.; Kim, D.W.; Choi, S.Y.; et al. Differential roles of exogenous protein disulfide isomerase A3 on proliferating cell and neuroblast numbers in the normal and ischemic gerbils. Brain Behav. 2020, 10, e01534. [CrossRef]

98. Paxinos, G.; Franklin, K.B.J. The Mouse Brain in Stereotaxic Coordinates; Academic Press: San Diego, CA, USA, 2001.

99. Hewitt, S.M.; Baskin, D.G.; Frevert, C.W.; Stahl, W.L.; Rosa-Molinar, E. Controls for immunohistochemistry: The Histochemical Society's standards of practice for validation of immunohistochemical assays. J. Histochem. Cytochem. 2014, 62, 693-697. [CrossRef]

100. Cao, Y.; Mao, X.; Sun, C.; Zheng, P.; Gao, J.; Wang, X.; Min, D.; Sun, H.; Xie, N.; Cai, J. Baicalin attenuates global cerebral ischemia/reperfusion injury in gerbils via anti-oxidative and anti-apoptotic pathways. Brain Res. Bull. 2011, 85, 396-402. [CrossRef]

Publisher's Note: MDPI stays neutral with regard to jurisdictional claims in published maps and institutional affiliations.

(C) 2020 by the authors. Licensee MDPI, Basel, Switzerland. This article is an open access article distributed under the terms and conditions of the Creative Commons Attribution (CC BY) license (http://creativecommons.org/licenses/by/4.0/). 